\title{
The Regime of Passage Through the Danish Straits
}

\author{
Alex G. Oude Elferink* \\ Netherlands Institute for the Law of the Sea, \\ Utrecht University, The Netherlands
}

\begin{abstract}
The Danish Straits are the main connection between the Baltic Sea and the world oceans. The regime of passage through these straits has been the subject of extensive regulation, raising the question how different applicable instruments interact. Apart from applicable bilateral and multilateral treaties, it is necessary to take into account the practice of Denmark and Sweden and other interested states, and regulatory activities within the framework of the IMO. The Case Concerning Passage Through the Great Belt before the ICJ provides insights into the views of Denmark and Finland. The article concludes that an 1857 treaty cxcludes the applicability of Part III of the LOS Convention to the straits, and that there are a number of difficulties in assessing the contents of the regime of the straits. At the same time, these uncertainties do not seem to have been a complicating factor for the adoption of measures to regulate shipping traffic.
\end{abstract}

\section{Introduction}

The Danish Straits are the main connection between the Baltic Sea and the world oceans. The straits are of vital importance for the maritime communication of the Baltic states and squarely fall within the legal category of straits used for international navigation. ${ }^{\prime}$ For a number of these states the Baltic Sea is the only outlet to the oceans (Estonia, Finland, Latvia, Lithuania and Poland). Although

* An earlier version of this article was presented at the international conference, The Passage of Ships Through Straits, sponsored by the Defense Analyses Institute, Athens, 23 October 1999. The author wishes to thank the speakers and participants at that conference for the stimulating discussions, which assisted in preparing the final version of the article. The author also wishes to thank Erik Molenaar for his comments on an earlier version of this article. The present version of the article was finalised in November 1999.

1 For an authoritative statement of what constitute international straits, see the judgment of the International Court of Justice in the Corfu Channel Case (Merits) (United Kingdom v Albania), [1949] ICJ Rep 4 at 28-29.

THE INTERNATIONAL JOURNAL OF MARINE AND COASTAL LAW, Vol 15, No 4

(C) Kluwer Law International, 2000 
the other states bordering the Baltic Sea (Denmark, Germany, the Russian Federation and Sweden) also border on other seas, the Baltic Sea still provides them with an important outlet to the world oceans. History illustrates the importance of the Danish Straits as an access route to and from the Baltic Sea. Over the last centuries, Baltic Sea and extra regional powers have sought to gain control over the straits and their present legal regime in part is an outcome of this struggle. ${ }^{2}$ In 1857 Denmark concluded two treaties with, respectively, a number of European states and the United States on the abolition of dues which Denmark levied in the Danish Straits. ${ }^{3}$ These treaties, which are still in force, also specify some basic rules applicable to navigation in the straits.

This article assesses the significance of the provisions of these two treaties for the present legal regime of the Danish Straits in the light of other relevant rules of international law. ${ }^{4}$ The 1958 Convention on the Territorial Sea and the Contiguous Zone ${ }^{5}$ and the 1982 Convention on the Law of the Sea ${ }^{6}$ contain provisions which apply to straits used for international navigation and customary law is also relevant in this respect. The international legal regime applicable to shipping in the Danish Straits was discussed extensively in the Case Concerning Passage Through the Great Belt (Finland v Denmark) before the International Court of Justice. Finally, to appreciate the regime applicable to shipping in the Danish Straits, it is necessary to look at measures which have been adopted in the framework of the International Maritime Organization (IMO) and the practice of the two states bordering the Danish Straits, Denmark and Sweden. Before turning to these issues, some background information on the geographical setting is provided.

\section{The Geography of the Danish Straits}

The connection between the Baltic Sea and the North Sea is formed by the Skagerrak, the Kattegat, the Belts (Fehmarn, Samsö, Little and Great Belt)

2 See e.g. G. Alexandersson, The Baltic Straits (The Hague, Martinus Nijhoff Publishers, 1982), pp. $70-73$.

3 Treaty for the Redemption of the Sound Dues between Austria, Belgium, France, Great Britain, Hanover, the Hansa Towns, Mecklenburg-Schwerin, the Netherlands, Oldenburg, Prussia, Russia, Sweden-Norway and Denmark of 14 March 1857, 116 Consolidated Treaty Series 357; Convention for the Discontinuance of the Sound Dues between Denmark and the United States of 11 April 1857, 116 Consolidated Treaty Series 465. The United States concluded a separate treaty with Denmark because it did not want to participate in the conference on the abolition of the Sound dues. The United States feared that under certain circumstances such participation might be construed as a recognition of the right of Denmark to levy dues on ships in passage through the Danish Straits. This might have created an undesirable precedent in respect of other straits. E. Brüel, "Les Détroits Danois au Point de Vue du Droit International", (1936-I) Recueil des Cours de l'Ac'adémie de Droit International 609-690 at 618-619.

4 Only the regime applicable in peacetime is discussed here. On the regime in wartime, see Brüel, note 3 above at pp. 629-664; and D.P. O'Connell, The International Law of the Sea (ed. I.A. Shearer, Oxford, Clarendon Press, 1982), vol. I, pp. 324-326. 
and the Sound. ${ }^{7}$ The Danish Straits are formed by the Sound, the Great Belt and the Little Belt. Traditionally, only these three straits were wholly comprised within the territorial sea of the states bordering the entrances to the Baltic Sea, and the 1857 treaties are only applicable to passage through these straits. ${ }^{8}$ Following the general acceptance of 12 nautical miles as the maximum breadth of the territorial sea at the Third United Nations Conference on the Law of the Sea in the 1970s, the states bordering the entrances to the Baltic Sea (at present Denmark, Germany and Sweden) have also extended their territorial sea to this distance. ${ }^{9}$ A general extension of the territorial sea to this limit would have resulted in the creation of a number of straits used for international navigation in the sense of Part III of the LOS Convention. ${ }^{10}$ This concerns part of the Kattegat, the Samsö Belt and the Fehmarn Belt. All ships passing through the Great Belt also pass through these sea areas. The three states concerned have refrained from extending their territorial seas in these areas to 12 nautical miles, leaving an exclusive economic zone (EEZ) corridor. ${ }^{11}$ This was done to prevent

5 Convention on the Territorial Sea and the Contiguous Zone of 29 April 1958, 516 UNTS 205.

6 United Nations Convention on the Law of the Sea of 10 December 1982 (hereinafter LOS Convention), (1982) 21 ILM 1261; 1833 UNTS 3.

7 Another entrance to the Baltic Sea is the Kiel Canal, which is situated in German territory. The minimum depth of the Kiel Canal is 11 metres and the bridges over the canal leave a maximum clearance of 42 metres. Foreign merchant ships in the canal are accorded the same treatment as ships in German internal waters. Ships in transit are exempt from customs duties. Warships and other non-commercial ships must obtain prior permission through diplomatic channels for passage through the canal (Memorial of the Government of the Republic of Finland (December 1991) in the Case Concerning Passage Through the Great Belt (Finland v Denmark), p. 14).

8 Before establishing a 12 nautical mile territorial sea, Denmark and Germany claimed a three nautical mile territorial sea and Sweden a four-nautical-mile territorial sea.

9 Act No. 200 of 7 April 1999 on the Delimitation of the Territorial Sea and Executive Order No. 242 of 21 April 1999 concerning the Delimitation of Denmark's Territorial Sea (English translation provided to the author by Mr J.R. Lilje-Jensen of the Royal Danish Ministry of Foreign Affairs); Proclamation of 11 November 1994 by the Government of the Federal Republic of Germany Concerning the Extension of the Breadth of the German Territorial Sea (UN Law of the Sea Bulletin 27, p. 55); Act Concerning the Territorial Waters of Sweden of 3 June 1966 as amended on 20 December 1979 (The Law of the Sea: National Claims to Maritime Jurisdiction (New York, United Nations, 1992), p. 126).

10 Germany acceded to the LOS Convention on 14 October 1994 and Sweden ratified it on 25 June 1996. Denmark is not a party to the Convention. Whether Part III of the Convention reflects customary international law is not completely clear (see e.g. R. Churchill and A. Lowe, The Law of the Sea (Manchester, Manchester University Press, 3rd ed., 1999), p. 113).

11 See the Explanatory Memorandum to the Bill concerning the extension of the Danish territorial sea to 12 nautical miles (Forslag til lov om afgransning af soterritoriet (Skriftlig fremsættlese (8 Oktober 1998))). Denmark and Sweden agreed in 1979 that if they would extend their territorial sea to 12 nautical miles they would leave a corridor of high seas of six nautical miles between the outer limits of their territorial sea in a number of places to maintain the same freedom of passage in these waters (Exchange of Notes Constituting an Agreement between Denmark and Sweden Concerning the Delimitation of the Territorial Waters between Denmark and Sweden of 25 June 1979 (The Law of the Sea: Maritime Boundary Agreements (1970-1984) (New York, United Nations, 1987), p. 18)). 
the creation of new straits is the sense of Part III of the LOS Convention. ${ }^{12}$ The LOS Convention provides that Part III on transit passage does not apply to a strait used for international navigation if there exists through the strait a route through the high seas or EEZ of similar convenience with respect to navigational and hydrographic characteristics. ${ }^{13}$ Part of the so-called Route $T,{ }^{14}$ the main route between the Baltic Sea and the North Sea, passes in a number of instances through the extended Danish territorial sea. ${ }^{15}$ To the extent that there is no route through the EEZ of similar convenience, under Part III of the LOS Convention the regime of transit passage would apply to these parts of Route T.16 Denmark considers that the regime of transit passage does not apply and also will not apply to these parts of its territorial sea, as there is no significant difference between Route $T$ and the routes beyond the territorial sea in these areas. In other areas, where there are no alternative routes, Route $T$ has not been included in the extended Danish territorial sea. ${ }^{17}$

The straits forming part of the Danish Straits provide three alternative entrance routes to the Baltic Sea. Of the three straits, the Little Belt has least significance for international navigation. The Little Belt is enclosed within the baselines of the territorial sea of Denmark and is part of Danish internal waters. Navigational conditions in the Little Belt can be difficult, due to the existence of shoals and strong currents. The Little Belt has a minimum depth of 11.8 metres. In May 1935 a bridge over the Little Belt was opened which restricted passage to ships with a maximum height of less than 33 metres. The Sound, which is situated between the coasts of Denmark and Sweden, provides the most direct

Forslag til lov om afgransning af soterritoriet (Skriftlig fremsættlese (8 Oktober 1998)). Denmark in two cases extended its territorial sea to 12 nautical miles resulting in the cancellation of existing EEZ corridors in straits used for international navigation. This concerns straits between the Danish mainland coast and the Danish islands of Laesö and Anholt. As in these cases there exists seaward of the islands a route through the EEZ of similar convenience with respect to navigational and hydrographic characteristics, under the LOS Convention the regime of transit passage does not apply to these straits (LOS Convention, Art. 38(1)). Under the LOS Convention there exists a right of non-suspendable innocent passage through such straits (ibid., Art. 45).

This also was, to a more limited extent, the case before Denmark extended its territorial sea to 12 nautical miles.

16 What constitutes a route of similar convenience in part depends on the type of ship involved. In some cases, there may exist a route of similar convenience for certain ships but not for others (see further S.N. Nandan and D.H. Anderson, "Straits Used for International Navigation: A Commentary on Part III of the United Nations Convention on the Law of the Sea 1982", (1989) 60 British Yearbook of International Law 159-204 at 177; M.H. Nordquist, United Nations Convention on the Law of the Sea 1982: A Commentary (Dordrecht, Martinus Nijhoff, 1993), vol. II, p. 314). Moreover, it can be argued that aircraft of a ship for which there is no route of similar convenience have a right of transit passage over the strait.

17 Information provided by Mr J.R. Lilje-Jensen of the Royal Danish Ministry of Foreign Affairs to the author. 
access route to the Baltic Sea. ${ }^{18}$ In two channels to the east and west of the island of Saltholm in the southern part of the Sound, there is a maximum depth of respectively 7.1 and 7.7 metres. The Great Belt has a significantly greater depth than the Sound and the Little Belt, ranging between 20 and 25 metres. In normal conditions navigation through the Great Belt does not pose particular difficulties, although weather and climatic conditions sometimes may cause problems. ${ }^{19}$ In 1998 the construction of a fixed link over the Great Belt was completed. The bridge over the western channel of the Great Belt has a vertical clearance of 18 metres. The vertical clearance of the suspension bridge over the eastern (main) channel is 65 metres.

\section{Regime Applicable to Shipping in the Danish Straits}

\section{The 1857 Treaties on the Sound Dues}

The Treaty for the Redemption of the Sound Dues between Denmark and a number of European States of 14 March 1857 provides that no ship shall in passing the Sound or the Belts be subjected to any detention or hindrance. ${ }^{20}$ This commitment has been made erga omnes, as has been explicitly recognised by Denmark. ${ }^{21}$ Moreover, the Treaty creates obligations for Denmark with respect to the maintenance of navigational aids and pilotage. ${ }^{22}$ Pilotage shall be available to foreign ships on a voluntary basis. These obligations are not only applicable to the straits themselves, but also to an undefined area outside the straits. ${ }^{23}$ The Convention for the Discontinuance of the Sound Dues between Denmark and the United States provides for the freedom of navigation of the Sound and the Belts of US vessels and their cargoes. ${ }^{24}$ This seems to exclude erga omnes application similar to the 1857 Treaty. The Convention contains similar provisions as the 1857 Treaty with respect to navigational aids and pilotage. ${ }^{25}$

Denmark and Sweden delimited their territorial sea in the Sound in 1932 (Declaration between the Danish and the Swedish Governments Concerning the Boundaries of the Sound of 30 January 1932; reproduced in Limits in the Sea No. 26: Territorial Sea Boundary: DenmarkSweden, p. 1). The boundary is a median line, which in one instance does not give any weight to the Danish island of Drogden and in another gives no weight to the Swedish island of Ven.

19 Information on the characteristics of the Danish Straits has been taken from the Memorial of the Government of the Republic of Finland (December 1991) in the Case Concerning Passage Through the Great Belt (Finland v Denmark), pp. 12-13. Art. 1.

See further Written Observations by the Government of the Kingdom of Denmark relating to the Request for Indication of Provisional Measures (June 1991) in the Case Concerning Passage Through the Great Belt (Finland v Denmark), pp. 26-27, para. 105; M. Koskenniemi, "Case Concerning Passage Through the Great Belt", (1996) 27 Ocean Development and International Law $255-289$ at $261-262$.

Arts 2(1)-(3)

The 1857 Treaty makes reference to the facilitation of traffic in the Kattegat, the Sound and the Belts. The 1857 Convention with the United States only makes reference to the Sound and the Belts

25 Art. I. Art. II. 
One important implication of the existence of these treaties is that Article 35(c) of the LOS Convention applies to the Danish Straits. This Article provides that nothing in Part III of the LOS Convention affects "the legal regime in straits in which passage is regulated in whole or in part by long-standing international conventions in force specifically relating to such straits". ${ }^{26}$

\section{The Nature of the Right of Passage}

The fact that the legal regime of the Danish Straits is not affected by Part III of the LOS Convention raises the question to what extent the regime in these straits is different from the regime contained in Part III of the Convention. In the Case Concerning Passage Through the Great Belt, Denmark submitted that the right of passage was based on Article 2 of the 1857 Treaty, "supplemented by the customary rules of international law related to the Danish Straits". ${ }^{27}$ This seems to suggest that there is a particular regime under customary law for the Danish Straits (in combination with the 1857 Treaty), different from the customary law regime applicable to straits in general. Earlier, the Danish Government had taken the position that the 1857 Treaty had been intended to bring the Danish Straits "under the general rules of international law relating to straits connecting two portions of the open sea". ${ }^{28}$

If the position of Denmark in the Case Concerning Passage Through the Great Belt is accepted, the regime of passage in the Danish Straits to a large extent would seem to be isolated from changes in the general regime of straits under customary international law. On the other hand, if the regime of the Danish Straits is that of general customary international law, changes in this latter regime in principle also apply to the Danish Straits. For instance, if it is

In its Declaration upon ratification of the LOS Convention Sweden stated that: "It is the understanding of the Government of the Kingdom of Sweden that the exception from the transit passage regime in straits provided for in article $35(\mathrm{c})$ of the Convention is applicable to the strait between Sweden and Denmark (Oresund [Sound]), as well as to the strait between Sweden and Finland (the Aland islands). Since in both those straits the passage is regulated in whole or in part by long-standing international conventions in force, the present legal regime in the two straits will remain unchanged." (UN Law of the Sea Bulletin 32, p. 11). As Denmark is not a party to the LOS Convention, Art. 35(c) is not of relevance for the part of the straits comprised in Danish maritime zones as treaty law. In the Case Concerning Passage Through the Great Belt, Denmark contended that, if the regime of transit passage had become part of customary international law, Art. 35(c) must be applied as an intrinsic part thereof (Counter-Memorial of Denmark (May 1992) as referred to in Koskenniemi, note 21 above, p. 261). On the Danish role in the negotiations concerning Art. 35(c) during the Third United Nations Conference on the Law of the Sea, see F. Laursen, Small Powers at Sea (Dordrecht, Martinus Nijhoff Publishers, 1993), pp. $50-53$ Counter-Memorial of Denmark (May 1992) as cited in Koskenniemi, note 21 above, p. 261.

28 Views of the Government of Denmark on Point I of the Bases of Discussion for the Conference for the Codification of International Law (Maps and Annexes to the Memorial of the Government of the Republic of Finland (December 1991) in the Case Concerning Passage Through the Great Belt (Finland v Denmark), Annex 12 (original source League of Nations, Conference for the Codification of International Law, Bases of Discussion Drawn Up by the Preparatory Committee, Territorial Waters, vol. II, Doc. C. 74, M. 39 (1929), p. 13)). 
established that the regime of transit passage has become customary law, it would in this latter case also be applicable to the Danish Straits.

In the Case Concerning Passage Through the Great Belt, Denmark further argued that the ascertainment of the right of passage had to take its starting point from Denmark's sovereignty. ${ }^{29}$ Consequently, the right of passage was also regulated by Danish national laws. ${ }^{30}$ Denmark concluded that the right thus defined consisted of non-suspendable innocent passage. ${ }^{31}$

A right of passage also applies to parts of the straits which are included within the internal waters enclosed by the system of straight baselines established by Denmark. ${ }^{32}$

To establish the actual content of the regime of passage, recourse can be had to the 1857 Treaty and practice of the coastal and user states. The 1857 Treaty provides that no ship shall in passing the Sound or the Belts be subjected to any detention or hindrance. ${ }^{33}$ Article I of the 1857 Treaty further specifies that

For instance. the Act on the Protection of the Marine Environment of 30 June 1993, as amended, applies to foreign ships in the Danish internal waters and territorial sea (Art. $2(1)(1))$ and makes no exception in respect of the Danish Straits. The same applies to the Order Concerning the Application of the Safety of Ships, Etc. Act to Foreign Ships (see Art. 1(1)). On the other hand, Danish legislation on the passage of foreign warships makes a distinction between the territorial sea in general and the Danish Straits (see further notes $48 f f$ below). Foreign ships have to follow sailing directions established by Denmark, which generally implement IMO regulations (see also below). Sweden also appears to apply its environmental regulations to all foreign ships in its territorial sea, without making an exception for the Sound (see M. Jacobsson, "Sweden and the Law of the Sea", in T. Treves and L. Pineschi (eds), The Law of the Sea: The European Union and its Member States (The Hague, Martinus Nijhoff, 1997), pp. 495-520 at p. 511).

31 Counter-Memorial of Denmark (May 1992) as cited in Koskenniemi, note 21 above, p. 261. Such a right of non-suspendable innocent passage also exists under Art. 16(4) of the Convention on the Territorial Sea and the Contiguous Zone, to which Denmark is a party. Denmark accepts that this provision is applicable to the Danish Straits (Written Observations by the Government of the Kingdom of Denmark relating to the Request for Indication of Provisional Measures (June 1991) in the Case Concerning Passage Through the Great Belt (Finland v Denmark), p. 26, para. 100). Finland did not indicate clearly what regime it considered to be applicable to the Danish Straits. Instead, Finland argued that under all potentially applicable regimes, the rights claimed by it existed (see Memorial of the Government of the Republic of Finland (December 1991) in the Case Concerning Passage Through the Great Belt (Finland v Denmark), pp. 122-130). Art. 4 of the 1999 Act on the Delimitation of the Territorial Sea provides that: "The existing right of passage enjoyed by foreign vessels through those parts of the [internal waters] of the Little Belt, the Great Belt and the Sound which are normally used for such passage shall remain unchanged." A similar provision was contained in Art. 3 of Order No. 437 on the Delimitation of the Territorial Sea of 21 December 1966, which was revoked by the 1999 Act. This approach is in conformity with Art. 5 of the Convention on the Territorial Sea and the Contiguous Zone and Arts 8 and 35(a) of the LOS Convention.

33 It is considered that the conclusions with respect to the 1857 Treaty apply mutatis mutandis to the Convention between Denmark and the United States. Art. IV of the Convention provides for most favourable nation treatment of United States ships through the Sound and Belts, implying that the United States in any case enjoys the same rights as states parties to the 1857 Treaty. 
passage includes anchoring or putting into port due to conditions of the sea or commercial operations.

The most important implication of this provision seems to be that Denmark cannot take any enforcement action against foreign ships, which otherwise would have been available under international law. ${ }^{34}$ On the other hand, this provision does not exclude that Denmark can adopt legislation which is applicable to ships in passage. ${ }^{35}$ This legislation has to be in conformity with the requirements of international law in this respect. ${ }^{36}$ Finally, the requirement not to detain or hinder ships of the 1857 Treaty only applies to ships in passage. Consequently, Denmark can take enforcement action against ships which are not exercising this right of passage as defined in the 1857 Treaty. Also in this case, Danish action would have to be in conformity with the requirements of the relevant provisions of general international law.

Information on the kind of (enforcement) action Denmark has taken in respect of foreign ships in the Danish Straits is not easily accessible, making it difficult to assess to what international regime this practice conforms. There have been various incidents of foreign ships exercising a right of passage beyond innocent passage. In some cases this was done deliberately and in other cases unintentionally. The normal Danish response is that the military report an incident to the Danish Ministry of Defence, which then sends a note to the embassy of the flag state. In case of repeated violations by ships of the same state, the Danish Ministry of Foreign Affairs may contact the embassy of the state involved to try to correct misunderstandings. Normally, the Danish response is solely diplomatic. ${ }^{37}$ Danish authorities generally do not resort to enforcement against ships, but use guidance instead. For instance, if a ship is violating the right of innocent passage by anchoring, the Danish authorities will contact the ship and ask it to get a permission or leave. ${ }^{38}$

Article 2 of the 1857 Treaty contains certain obligations of Denmark in respect of navigational aids and pilotage. Under this provision, Denmark is excluded from establishing a system of compulsory pilotage in the Danish Straits. ${ }^{39}$ Other

See also Churchill and Lowe, note 10 above at p. 114; and E. Molenaar, Coastal State Jurisdiction over Vessel-Source Pollution (The Hague, Kluwer Law International, 1998), p. 309. Enforcement powers in straits used for international navigation in any case are limited in comparison to other parts of the territorial sea (see LOS Convention, Art. 233). See also note 30 above.

36 See also Churchill and Lowe, note 10 above at p. 114.

37 E-mail of 25 November 1999 of Mr Hans Henrik Larsen of the Royal Danish Ministry of Defence to the author.

$38 \mathrm{Ibid}$. The author of the e-mail was not aware of force ever having been used against a foreign ship in this context.

39 Resolution A.579(14) of 20 November 1985 of the Assembly of the IMO recommends the use of pilotage services established by the Governments of Denmark and Sweden in a defined area of the Sound for certain types of ships and ships carrying certain cargoes. Resolution A.620(15) of 19 November 1987 of the Assembly of the IMO contains a similar recommendation for certain ships in navigation through the entrances of the Baltic Sea. 
measures to regulate maritime traffic in the Danish Straits are not excluded by Article 2 of the 1857 Treaty. Such measures have to be adopted in conformity with the relevant rules of international law.

\section{Regulation of Shipping Traffic}

A number of measures to regulate shipping traffic have been adopted by Denmark (and, where appropriate, Sweden) taking into account the procedures of the relevant regulatory instruments. In some cases, these allow a coastal state to adopt such measures unilaterally and in other instances this requires involvement of the IMO. ${ }^{40}$

The principal route for maritime traffic through the Danish Straits is the socalled Route T, which passes through the Great Belt. The development of this route was started in the 1960 s to meet increased traffic flows and growing ship sizes. ${ }^{41}$ In parts of Route $T$ traffic separation schemes and deep water routes have been established, through the procedures involving the IMO, as has also been the case for the Sound.

Further measures to regulate maritime traffic have been taken as a consequence of the project for a fixed link over the Great Belt. In 1991 Denmark established the Vessel Traffic System (VTS) Great Belt Traffic. The VTS was made mandatory for the western channel in order to be able to stop ships over 1,000 GRT or with a height of over 18 metres from attempting to pass under the low West Bridge. In the eastern channel, which is the main channel, the VTS was voluntary. ${ }^{42}$ The eastern channel is crossed by a suspension bridge, which has a clearance of 65 metres. In 1996 IMO's Maritime Safety Committee adopted a mandatory ship reporting system (SRS) for the VTS Great Belt Traffic ${ }^{43}$ The reasons given by Denmark for making the submission concerning the SRS included the occurrence of a large number of serious incidents in the VTS Great Belt Traffic and the contravention by 25 ships over the previous year of Rule 10 on traffic separation schemes of the Regulations for Preventing Collisions at Sea (COLREGS), $1972 .{ }^{44}$ Denmark further informed the IMO that failure to comply with the SRS would be reported to the flag state for further action following the same procedure as in the case of infractions of Rule 10 of the COLREGS. 45

40 See also LOS Convention, Art. 41.

41 A. Nissen, "Route T; A Major Danish Waterway" (Maps and Annexes to the Memorial of the Government of the Republic of Finland (December 1991), Annex 1, pp. 23-30 at pp. 24-25).

42 See G. Plant, "The Relationship between International Navigation Rights and Environmental Protection: A Legal Analysis of Mandatory Ship Traffic Systems", in H. Ringbom (ed.), Competing Norms in the Law of Marine Environmental Protection (London, Kluwer Law International, 1997), pp. 11-30 at p. 15 n. 16.

43 Resolution MSC. 63(67) and Annex 1 (reproduced in Doc. MSC 67/22/Add.1, Annex 13, pp. 111).

44 Convention on the International Regulations for the Prevention of Collisions at Sea of 20 October 1972, 1050 UNTS 17.

45 See Doc. NAV 42/23, Annex 8. 


\section{Passage of Warships}

The 1857 treaties are not applicable to warships (or other government ships operated for non-commercial purposes). ${ }^{46}$ In their regulations concerning the passage of warships and other government ships operated for non-commercial purposes, Denmark and Sweden have made special provision for passage through the Danish Straits. Until 1994, Sweden required prior notification of passage of foreign warships through its territorial sea. Such notification was not required for passage through the Swedish territorial sea in the Sound ${ }^{47}$ Although this is not explicitly indicated, the provisions of the relevant ordinance indicate that the regime of passage is that of innocent passage.

Danish regulations accord foreign warships a right of innocent passage within the meaning of international law through the Danish territorial sea. ${ }^{48}$ Submarines are required to navigate on the surface in the Danish territorial sea. ${ }^{49}$ The right of innocent passage also exists in the Danish Straits. Simultaneous passage of the Great Belt or the Sound of more than three warships of the same nationality is subject to prior notification through diplomatic channels. ${ }^{50}$ There have been incidents with more than three ships passing at the same time through the Great Belt, but usually the flag state complies with the applicable Danish rules. ${ }^{51}$ The passage of warships of the Hollaenderdyb and Drogden, parts of the Sound comprised within Danish internal waters forming part of the roadstead of Copenhagen and the Little Belt, which also forms part of Danish internal waters, is subject to advance notification. ${ }^{52}$

Art. 1 of the 1857 Treaty makes reference to the detention or hindrance of any ship. However, the context of this reference indicates that only merchant ships are intended. The 1857 Convention makes reference to "freedom of navigation of ... American vessels and their cargoes" (Art. I); see also K. Bangert, "Denmark and the Law of the Sea", in T. Treves and L. Pineschi (eds), The Law of the Sea: The European Union and its Member States (The Hague, Martinus Nijhoff, 1997), pp. 97-125 at p. 106; J.A. Roach and R.W. Smith, United States Responses to Excessive Maritime Claims (The Hague, Martinus Nijhoff, 2nd ed., 1996), p. 354. Ordinance Concerning the Admission to Swedish Territory of Foreign State Vessels and State Aircraft of 19 March 1992, section 3. In 1994 Sweden abandoned the prior notification requirement (see Jacobsson, note 30 above at p. 500).

48 Ordinance Governing the Admission of Foreign Warships and Military Aircraft to Danish Territory in Time of Peace of 16 April 1999, Art. 1(3).

Ibid., Art. 6(2).

50 Ibid., Art. 3(2). A similar requirement was contained in the Ordinance which was repealed by the 1999 Ordinance. This former Ordinance required prior notification for the passage of warships through the Danish territorial sea, except where navigation of the territorial sea takes place in connection with the passage of the Great Belt, the Samsö Belt or the Sound (Ordinance Governing the Admission of Foreign Warships and Military Aircraft to Danish Territory in Time of Peace of 27 February 1976, Arts 3(1) and 3(2)). Simultaneous passage of the territorial sea other than the Great Belt, Samsö Belt or the Sound of more than three warships of the same nationality required advance permission (ibid., Art. 3(4)).

51 E-mail of 25 November 1999 of Mr Hans Henrik Larsen of the Royal Danish Ministry of Defence to the author.

52 Ordinance Governing the Admission of Foreign Warships and Military Aircraft to Danish Territory in Time of Peace of 16 April 1999, Art. 4(2). An identical requirement was contained in 
The positions of Denmark and Sweden concerning passage of warships is not shared by all other states. The view of the United States is that warships have either the customary right of transit passage or the conventional right of "free and unencumbered navigation", since transit passage is more restrictive than freedom of navigation guaranteed under the 1857 treaties. ${ }^{53}$ As was noted above, it is doubtful that the 1857 treaties also apply to warships. Whether the generally existing customary law regime of passage of warships through straits has been altered by state practice in respect of the Danish Straits would require a more detailed analysis. ${ }^{54}$

\section{Conclusions}

As was pointed out at the beginning of this article, the regime of straits is not only relevant for the Danish Straits, but also for the entrances to the Baltic Sea in general. A comprehensive extension of the territorial sea to 12 nautical miles by Denmark, Germany and Sweden would have led to the creation of a number of new straits used for international navigation. The states involved have opted in some cases not to extend their territorial sea to this maximum to prevent the creation of such new straits. In two cases, Denmark has included straits in its 12 nautical mile territorial sea. In these cases the regime of transit passage is not applicable as there is a route of similar convenience beyond the territorial sea.

The existence of the 1857 Treaty implies that the regime of the Danish Straits will not be affected by Part III of the LOS Convention if Denmark will proceed with the ratification of the Convention. What the exact content of the present regime is, is not altogether clear. The 1857 Treaty only contains a very broad definition of the rights and obligations of the parties in respect of navigation. For instance, it is not clear whether passage amounts to, e.g. (non-suspendable) innocent passage or transit passage and in what instances a ship is no longer in passage and what implications this has for the enforcement of regulations by the coastal state. Under a regime of innocent passage, there exist more restrictions for ships in passage than under a regime of transit passage. Denmark considers that the regime is that of innocent passage. Moreover, Denmark seems to hold that the regime of the Danish Straits is a special regime, which implies that any changes in customary law applicable to straits in general do not become

cont.

Art. 4(2) of the 1976 Ordinance. In other parts of internal waters, warships may only pass or stay when prior permission for such passage or stay has been obtained through diplomatic channels (Art. 4(2)).

53 M. Nash Leich, Cumulative Digest of United States Practice in International Law 1981-1988: Book II (Office of the Legal Adviser; Department of State), p. 2025.

54 No reference to specific United States actions (apart from the United States view as given above) is made in Roach and Smith, note 46 above. As this book reports on responses of the United States against maritime claims of other states which the United States considers to go beyond what is permitted under international law, this would seem to suggest that no further actions have been taken to assert United States rights in this case. 
automatically applicable to the Danish Straits. Certain aspects of the regime of the straits, such as the passage of warships, are not covered by the 1857 Treaty.

A further difficulty in assessing the contents of the regime of the Danish straits is the absence of detailed information on practice which can assist in its clarification. This concerns such areas as enforcement of Danish legislation applicable to foreign ships and the regime of passage of warships. The available information seems to suggest that Denmark approaches these issues with caution.

The existence of the 1857 Treaty does not seem to have been a complicating factor for the adoption of measures to regulate traffic. The strait states have followed the generally applicable procedures, and there do not seem to be any indications that in the absence of the 1857 Treaty this process would have been significantly different.

To a certain extent the concluding observation of Brüel in his 1936 Hague Academy lecture on the Danish Straits that Denmark prefers not to clearly define its position still holds true. ${ }^{55}$ Such an approach is understandable, taking into account the apparent efficacy of the present regime and the controversy a more assertive approach might raise.

55 Brüel, note 3 above at p. 690 . 